\title{
Physical Examination Supplemental Qualifiers Dataset
}

National Cancer Institute

\section{Source}

National Cancer Institute. Physical Examination Supplemental Qualifiers Dataset. NCI

Thesaurus. Code C147234.

A dataset containing supplemental information, specifically non-standard variables, to parent records in the physical examination domain. 